\title{
Testosterone or $17 \beta$-estradiol exposure reveals sex-specific effects on glucose and lipid metabolism in human myotubes
}

\author{
Firoozeh Salehzadeh, Anna Rune, Megan Osler and Lubna Al-Khalili \\ Department of Molecular Medicine and Surgery, Karolinska Institutet, 17177 Stockholm, Sweden \\ (Correspondence should be addressed to L Al-Khalili who is now at Section of Integrative Physiology, Department of Molecular Medicine and Surgery, von Eulers \\ väg 4a, Karolinska Institutet, 17177 Stockholm, Sweden; Email: lubna.khalili@ki.se)
}

\begin{abstract}
Changes in sex hormone levels with aging or illness may lead to metabolic disorders. Moreover, the ratio changes in men versus women may have distinct pathological responses. Since little is known about sex hormone action on muscle metabolism, we examined the role of testosterone or $17 \beta$-estradiol $\left(\mathrm{E}_{2}\right)$ in metabolism and investigated whether either hormone may mediate a sex-specific effect. Myotubes from postmenopausal women and age-matched male donors were treated with $10 \mathrm{nM}$ testosterone or $\mathrm{E}_{2}$ for 4 days, and assays were performed to measure metabolic readouts, signal transduction, and mRNA expression. Testosterone and $\mathrm{E}_{2}$ treatment enhanced insulin-stimulated glucose incorporation into glycogen and AKT phosphorylation in myotubes from female donors, highlighting a sexspecific role of sex hormone in glucose metabolism. Testosterone treatment increased palmitate oxidation in
\end{abstract}

myotubes from both female and male donors, while $\mathrm{E}_{2}$ enhanced palmitate oxidation in myotubes from male donors only. Testosterone-mediated increase in palmitate oxidation was attenuated at the presence of androgen receptor antagonist, which may indicate a role of nuclear steroid receptor in muscle lipid oxidation. Testosterone treatment increased mRNA expression of the insulin receptor substrate 2 in myotubes from male and female donors, whereas it increased mRNA expression of glycogen synthase 1 only in myotubes from male donors. $E_{2}$ treatment increased pyruvate dehydrogenase kinase 4 mRNA expression in myotubes from female donors. Thus, our data suggest that testosterone or $\mathrm{E}_{2}$ modulates muscle glucose and lipid metabolism and may play a role in metabolism in a sex-dependent manner.

Journal of Endocrinology (2011) 210, 219-229

\section{Introduction}

The incidence of metabolic syndrome, also called insulin resistance syndrome, increases substantially during menopause (Polotsky \& Polotsky 2010) and advancing age. The free levels of sex hormones were decreased during aging, which may indicate an important role of sex hormones in metabolic homeostasis. Thus, the influence of sex hormones and relative risks for metabolic disease are commonly related to the circulating plasma level of the different sex hormones (Shoupe \& Lobo 1984, Haffner et al. 1994, 1996, van den Beld et al. 2000, Abate et al. 2002, Tivesten et al. 2007). Declined testosterone serum levels correlate to incidence of type 2 diabetes in men and is associated with aging (Grossmann et al. 2010), indicating an important role of testosterone in metabolism. Interestingly, estradiol replacement therapy in postmenopausal women may partially provide cardiovascular protection and is suggested to be both estrogen receptor (ER) dependent and independent (for review, Dubey \& Jackson (2001)). Moreover, cardiovascular disease is less common in premenopausal women when compared with age-matched men, and this observed sex difference is abolished after menopause in women (Mercuro et al. 2003), a finding attributed to altered levels of sex hormones with decreased female sex hormones.

Many lines of evidence point to gender aspects as a risk factor for metabolic disorders and highlight distinct roles of androgen and estradiol on whole-body metabolism (Roepstorff et al. 2002, Mercuro et al. 2003, Murphy \& Steenbergen 2007, Regitz-Zagrosek et al. 2007). Testosterone levels decline with age in men (Tenover et al. 1987), therefore testosterone replacement therapy in older men has become more of interest, and it is gaining an increasing interest and attention in the treatment of insulin resistance. Previously, the total normal circulating levels (free and bound) of testosterone and estrogen (measured at 8.86 and $0.12 \mathrm{nM}$ respectively) exhibited a strong correlation to body composition and muscle strength in elderly men (van den Beld et al. 2000).

Low-dose testosterone treatment in castrated male rats reduces blood glucose levels and increases skeletal muscle glycogen stores, whereas $17 \beta$-estradiol $\left(\mathrm{E}_{2}\right)$ has no effect. Thus, testosterone and $\mathrm{E}_{2}$ have differential effects on glucose metabolism in skeletal muscle (Ramamani et al. 1999). In addition to the role of sex hormones in glucose 
metabolism, these mediators also play a role in fat metabolism. Estradiol treatment reduces the expression of lipogenic genes in adipocytes from ovariectomized mice (D'Eon et al. 2005) and reduces lipid oxidation in skeletal muscle in ovariectomized rats (Campbell \& Febbraio 2001), while testosterone replacement enhances lipid metabolism and decreases fat depots in men (Zitzmann 2008). Estradiol hormone replacement in postmenopausal women exhibited positive changes on a wide range of metabolic parameters, including improved peripheral vascular reactivity, increased highdensity lipoprotein levels (Al-Khalili et al. 1998, Godsland 2001), reduced abdominal obesity, enhanced overall insulin sensitivity (Andersson et al. 1997), lower lipid levels, lower blood pressure (Salpeter et al. 2006, Lobo 2008), as well as prevention of new type 2 diabetes cases. Similarly, testosterone treatment of obese men with hypogonadism (Marin et al. 1992, Miner et al. 2008) decreased plasma insulin and glucose levels, improved the waist/hip ratio, and enhanced muscle strength (Marin et al. 1992).

Recent therapeutic strategies targeting sex hormones have been proposed (Casey \& Barkin 2008, Miner et al. 2008, Zitzmann 2008) for the treatment of type 2 diabetes through administration of sex steroids to reduce cardiovascular risk in both young and elderly patients. Clinical studies provide evidence for sex differences in insulin sensitivity and the pathogenesis of type 2 diabetes due to the specific effects of circulating testosterone and $\mathrm{E}_{2}$ (for review, Haffner (2000)). For example, a low testosterone level in men predicts insulin resistance and progression to type 2 diabetes, whereas an elevated testosterone level in women is associated with metabolic impairments (Haffner 2000, Oh et al. 2002). Since skeletal muscle is a major target organ for insulin-regulated glucose metabolism, it is possible that sex hormones may play a significant role in skeletal muscle metabolism and may have distinct sex-dependent metabolic effects on skeletal muscle derived from men versus women.

Thus, hormonal replacement therapy has a beneficial effect on total body metabolism and substrate utilization for aged subjects (Baltgalvis et al. 2010). The androgen receptor (AR) is expressed higher in young men compared with old men (Poole et al. 2011). As in aged subjects, estrogen is suggested to improve cellular stress via ER (Baltgalvis et al. 2010), and the $A R$ mRNA expression may change in response to exercise with respect to aging (Poole et al. 2011). Therefore, we speculate that sex hormone treatment of aged muscle should improve total cell metabolism and substrate turnover.

Currently, however, little is understood regarding the outcome of hormone replacement therapy with respect to the direct role of sex hormones on insulin action on skeletal muscle, the subsequent consequences on local lipid and glucose metabolism, and importantly, the impact on type 2 diabetes (Singh et al. 2002). Clearly, the role of sex hormones and intrinsic sex differences in skeletal muscle cell metabolism via sex hormone treatment is not well elucidated, and further investigations are warranted to unravel the role of sex hormones.
In this study, we isolated and cultured skeletal muscle cells derived from male and female donors in the presence of either testosterone or $\mathrm{E}_{2}$ and determined the effects on metabolism and gene expression. We have recently demonstrated that cultured skeletal muscle myotubes derived from postmenopausal women and age-matched male donors do not retain intrinsic sex differences in basal glucose and lipid metabolism (Rune et al. 2009). Given this finding, we hypothesized that sex hormone treatment plays an important role in metabolism in skeletal muscle cell, and intrinsic sex-related differences in metabolism may become apparent following sex hormone exposure. In this study, we provide evidence that testosterone and $E_{2}$ have differential effects on lipid and glucose metabolism and the mRNA expression of metabolic genes, as well as a sex-dependent influence on glucose incorporation into glycogen in myotubes from female and male donors. Thus, testosterone or $\mathrm{E}_{2}$ is involved in skeletal muscle metabolism, and the skeletal muscle cells retain a sexdependent response to sex steroids in an exogenous in vitro environment.

\section{Materials and Methods}

\section{Material}

DMEM, DMEM-F-12, fetal bovine serum (FBS), penicillin/streptomycin, and fungizone were obtained from Gibco (Invitrogen). Testosterone, $\mathrm{E}_{2}$, and CDX (Bicalutamide, AR antagonist) were purchased from Sigma-Aldrich. Charcoal/ dextran-treated FBS was from HyClone (Logan, UT, USA). Radioactive reagents $\left(\left[9-10(n)-{ }^{3} \mathrm{H}\right]\right.$ palmitate was purchased from Amersham or ${ }^{14} \mathrm{C}$-palmitate and ${ }^{14} \mathrm{C}$-glucose) were purchased from Perkin-Elmer (Perkin-Elmer Life Sciences, Inc., Boston, MA, USA).

\section{Subjects}

A cohort of healthy postmenopausal women and agematched (60 \pm 1 years) male volunteers (11 men and 10 women), with no family history of diabetes or heart disease, was selected based on clinical characteristics of body mass index for male $(27 \pm 0 \cdot 6)$ and for female $(30 \pm 1 \cdot 3)$ subjects (not significant and fasting glucose $(5 \cdot 3 \pm 0 \cdot 1 \mathrm{mmol} / \mathrm{l}$ ) as reported previously (Rune et al. 2009)). Urinalysis, blood chemistry, and measurements of blood pressure and anthropometric parameters were assessed at Karolinska University Hospital, Stockholm, Sweden, and were found to be normal. None of the male donors were under hormone replacement therapy. Of the female participants, one woman received estrogen replacement therapy, Vagifem $0.25 \mathrm{mg} 2 \mathrm{x} / \mathrm{w}$, a vaginal tablet that releases small amounts of estradiol locally into the vaginal tissues and is used at short term. This individual was included in all data analysis, since the obtained values for this study fell within a normal range. Skeletal muscle biopsies from vastus lateralis were obtained from 11 
male and 10 female donors of the cohort. The ethical committee at Karolinska Institutet approved all protocols and informed consent was received.

\section{Satellite cell culture}

Satellite cells were isolated from skeletal muscle biopsies by trypsin-EDTA digestion and cultured as described (Al-Khalili et al. 2003), with some modifications. Biopsies were washed in PBS supplemented with 1\% penicillin/streptomycin and $1 \%$ fungizone. Isolated satellite cells were propagated and differentiated into myotubes as described (Al-Khalili et al. 2003). Cells were studied at passage 3-5. Myotubes were cultured in DMEM supplemented with $2 \%$ charcoal/dextrantreated FBS and treated with $0 \cdot 1 \%$ ethanol as control, $10 \mathrm{nM}$ testosterone, or $10 \mathrm{nM} \mathrm{E}_{2}$ for 3 days. Media were replaced once a day and serum starvation occurred on the 4th day of treatment. An additional concentration of the testosterone or $\mathrm{E}_{2}(1 \mathrm{nM})$ was also used to determine the dose-response of sex hormones on palmitate oxidation. When the sex hormone receptor antagonist $10 \mathrm{nM}$ CDX (AR antagonist) was used, myotubes were treated with $0 \cdot 1 \%$ DMSO or CDX for at least $30 \mathrm{~min}$ before the addition of testosterone.

\section{Skeletal muscle cell differentiation}

Myotubes were grown on six-well plates for Giemsa-Wright staining as described previously (Al-Khalili et al. 2004). To assess the extent of myotubes differentiation by GiemsaWright staining, myotubes were fixed in methanol (10 $\mathrm{min})$, 1:10 Giemsa (15 min), and 1:10 Wright (20 min). Cells were washed with double-distilled $\mathrm{H}_{2} \mathrm{O}$, and mono- or multinucleated cells were observed under a phase contrast inverted light microscope. Cells were placed over a Bürker chamber, and total number of myotubes were counted in 20 squares $\left(0 \cdot 04 \mathrm{~mm}^{2}\right)$ using the $40 \times$ objective. Myotube formation and fusion rate after sex hormone stimulation were measured as percentage $>5$ nuclei/total myotubes $/ \mu \mathrm{m}^{2}$ over control. Moreover, the GLUT4 mRNA expression was chosen to be the specific skeletal muscle cell marker for cell differentiation (Al-Khalili et al. 2003).

\section{Quantitative real-time PCR}

mRNA was extracted from human myotubes of seven male and seven female subjects following 4 days of hormone treatment using a Qiagen RNAeasy Mini Kit (Qiagen), and cDNA was synthesized using SuperScript First-Strand Synthesis System for RT-PCR (Invitrogen). mRNA expression was analyzed by real-time PCR with the ABI PRISM 7000 Sequence Detector System (Applied Biosystems Life Technologies, Sweden). mRNA expression of genes involved in metabolism was determined, including glycogen synthase 1 (GYS1), insulin receptor substrate 1 (IRS1), TBC1 domain family member 1 (TBC1D1), glucose transporter 4; GLUT4 (SLC2A4) and pyruvate dehydrogenase kinase isozyme 4 (PDK4), carnitine palmitoyltransferase 1 (CPT1), IRS2, stearoyl-CoA desaturase $(S C D)$, peroxisome proliferator-activated receptor delta $(P P A R D)$ and gamma (PPARG), fatty acid translocase (CD36), sterol regulatory element-binding protein 1 (SREBP1; SREBF1), uncoupling protein 2 (UCP2), UCP3, and AMP-activated protein kinase alpha 2 (AMPKa2; $P R K A A 2)$. Sex hormone-specific genes including the enzyme P450 aromatase (P450arom; CYP19A1), the sex hormonebinding globulin $(S H B G), \operatorname{ER} \alpha(E R 1), E R \beta(E R 2)$, steroid5-alpha-reductase, alpha polypeptide 1 (SRD5A1), SRD5A2, and $A R$ were also measured. The primer/probes for all genes were purchased from $A B I$, with a FAM reporter. The relative abundance of the target transcript was calculated from duplicate samples after data were normalized against a housekeeping gene using CT comparative method. We tested three internal controls (housekeeping genes 18s, GAPDH, and $\beta 2$-microglobulin). The housekeeping gene $18 \mathrm{~s}$ was chosen for normalization to ensure highest accuracy of analysis and to standardize expression from myotubes.

\section{Free fatty acid oxidation}

${ }^{3} \mathbf{H}$ palmitate assay The assay was performed as described previously (Rune et al. 2009). In brief, myotubes obtained from female $(n=3)$ or male $(n=3)$ donors were grown in 12 -well plates, differentiated for 3 days, and treated for 4 days with either sex hormone in the presence or absence of the $0 \cdot 1 \%$ DMSO as control or CDX (Bicalutamide). After serum starvation overnight, myotubes were supplemented with $0 \cdot 2 \%$ fatty acid-free albumin from bovine serum and treated with $0 \cdot 5 \mu \mathrm{Ci}$ palmitic acid $\left[9-10(n)-{ }^{3} \mathrm{H}\right]+10 \mu \mathrm{M}$ cold palmitate in the presence or absence of 1 or $10 \mathrm{nM}$ testosterone or steroid receptor inhibitor (CDX) for 4-5 h (pre-incubated with CDX for $30 \mathrm{~min}$ and thereafter $30 \mathrm{~min}$ with testosterone). To absorb non-metabolized palmitate, $0 \cdot 2 \mathrm{ml}$ cell supernatant was mixed with $0.8 \mathrm{ml}$ charcoal slurry $(0.1 \mathrm{~g}$ charcoal powder in $1 \mathrm{ml}$ $0.02 \mathrm{~m}$ Tris-HCl buffer, $\mathrm{pH} 7 \cdot 5$ ) in a $2 \mathrm{ml}$ Eppendorf tube and shaken for $30 \mathrm{~min}$. Samples were subjected to centrifugation for $15 \mathrm{~min}$ at $20000 \mathrm{~g}$, after which $0 \cdot 3 \mathrm{ml}$ supernatant with tritium-bound water was withdrawn, and radioactivity was determined in a liquid scintillation counter (Win- Spectral 1414 liquid scintillation counter; Wallac, Turku, Finland). Each experiment was performed in duplicate.

${ }^{14} \mathrm{C}$ palmitate assay Assessment of free fatty acid oxidation was determined in myotubes from seven female and seven male subjects as described (Al-Khalili et al. 2006). Myotubes were grown in a $25 \mathrm{~cm}^{2}$ cell culturing flasks. At day 4 of treatment with either $10 \mathrm{nM} \mathrm{E}_{2}$ or $10 \mathrm{nM}$ testosterone, myotubes were serum-starved overnight and thereafter treated with palmitate $(0.4 \mu \mathrm{Ci})$. Myotubes were incubated in the presence or absence of either sex hormone, with or without $120 \mathrm{nM}$ insulin for $4.5 \mathrm{~h}$ (pre-incubated with either sex hormone for $30 \mathrm{~min}$ ). Following the addition of $35 \%$ perchloric acid to the media, released ${ }^{14} \mathrm{CO}_{2}$ was trapped in a filter soaked with 
solvable reagent (benzethonium hydroxide). The amount of released ${ }^{14} \mathrm{CO}_{2}$ was measured in a liquid scintillation counter (WinSpectral 1414 liquid scintillation counter, Wallac). Each experiment was performed on duplicate wells.

\section{Glucose incorporation to glycogen}

Glucose incorporation to glycogen was determined in myotubes from seven female and seven male subjects, as described previously (Al-Khalili et al. 2003). After 3 days of treatment with either $10 \mathrm{nM} \mathrm{E}_{2}$ or $10 \mathrm{nM}$ testosterone, myotubes were serum-starved overnight in the presence of either hormone. To assess glucose incorporation to glycogen, myotubes were incubated in the absence or presence of sex hormones and treated with $120 \mathrm{nM}$ insulin for $30 \mathrm{~min}$ before adding $\mathrm{D}_{-}\left[\mathrm{U}_{-}{ }^{14} \mathrm{C}\right]$ glucose $(1 \mu \mathrm{Ci} / \mathrm{ml})$ for the last $90 \mathrm{~min}$ at day 5. $\left[{ }^{14} \mathrm{C}\right]$-labeled glycogen was counted in a liquid scintillation counter (WinSpectral 1414 liquid scintillation counter, Wallac). Each experiment was performed in duplicate.

\section{Western blot analysis}

Overnight serum-starved myotubes were treated with either sex hormone with or without $120 \mathrm{nM}$ insulin for $20 \mathrm{~min}$. Cells were harvested, pooled, and processed for western blot analysis as described previously (Al-Khalili et al. 2003). Total protein antibodies and phospho-specific antibodies AMPK $^{\text {thr172 }}$ (CHEMICON/Upstate/Linco, Sweden), $\mathrm{AKT}^{\mathrm{ser} 473}, \mathrm{pIRS}^{\mathrm{ser} 636}, \mathrm{p} 70^{\mathrm{s} 6 \mathrm{k}}, \mathrm{p} 38$, and ERK $1 / 2$ mitogen-activated protein kinase (MAPK) (all from Cell Signaling Technology, Sweden) were used. Total expression and phosphorylation of each target protein were quantified on the same membrane. A GAPDH (Cell Signaling Technology) antibody was used to confirm equal loading of proteins. Proteins were separated by $12-6 \%$ gradient SDS-PAGE, transferred to polyvinylivenediflouride membrane (Millipore, Bedford, MA, USA), and blocked in 7.5\% non-fat dried milk in Tris-buffered saline with $0 \cdot 02 \%$ Tween (TBST) for $2 \mathrm{~h}$ at room temperature. Membranes were incubated overnight at $4{ }^{\circ} \mathrm{C}$ with total or phospho-specific antibodies (1:1000 dilution). After washing in TBST, the membranes were incubated with a HRP-labeled anti-rabbit IgG secondary antibody for all target proteins (1:25 000, Bio-Rad) for $1 \mathrm{~h}$ at room temperature, followed by additional washing in TBST. Proteins were visualized by enhanced chemiluminescence (Amersham) and quantified by densitometry (Al-Khalili et al. 2003).

\section{Statistical analysis}

Data are presented as mean \pm s.E.M. Changes for comparison for factor 'sex' (female versus male at each condition) or factor 'hormone treatment' (testosterone versus control or $\mathrm{E}_{2}$ versus control) were analyzed using two-way ANOVA, one factor repeated measurement for the basal group and for the insulinstimulated group for signaling and metabolic data. A similar test was used for mRNA expression data analysis. A value of $P<0 \cdot 05$ was considered as significant. The analysis was performed using SigmaStat 3.5.

\section{Results}

\section{Sex hormone effect on differentiation}

Exposure to $10 \mathrm{nM}$ testosterone or $\mathrm{E}_{2}$ for 4 days did not lead to alterations in cell growth, differentiation, or appearance of myotubes, as assessed by the Giemsa-Wright staining of the myotubes under light microscopy (data not shown), compared with the untreated cells. To minimize the effect of external sex hormones, which might present in FBS,

Table 1 Unaltered mRNA expression of selected genes assessed in myotubes obtained from female and male donors after sex hormone exposure. Myotubes were treated with vehicle as control $(0 \cdot 1 \%$ ethanol), $10 \mathrm{nM} 17 \beta$-estradiol, or testosterone for 4 days. Results are mean \pm S.E.M. for $n=7$ female subjects and $n=7$ male subjects. Results were normalized to $18 \mathrm{~s} r R N A$, and all the values are multiplied by $10^{-6}$

\begin{tabular}{|c|c|c|c|c|c|c|}
\hline & \multicolumn{2}{|l|}{ Control } & \multicolumn{2}{|l|}{$17 \beta$-Estradiol } & \multicolumn{2}{|l|}{ Testosterone } \\
\hline & Female & Male & Female & Male & Female & Male \\
\hline \multicolumn{7}{|l|}{ Genes } \\
\hline$A M P K \alpha 2$ & $0 \cdot 64 \pm 0 \cdot 12$ & $0 \cdot 64 \pm 0 \cdot 11$ & $0 \cdot 60 \pm 0 \cdot 09$ & $0.47 \pm 0.09$ & $0 \cdot 55 \pm 0 \cdot 08$ & $0.66 \pm 0.17$ \\
\hline$C D 36$ & $101 \cdot 96 \pm 7 \cdot 74$ & $109 \cdot 25 \pm 29 \cdot 10$ & $83 \cdot 23 \pm 17 \cdot 98$ & $120 \cdot 18 \pm 27 \cdot 09$ & $93 \cdot 95 \pm 15 \cdot 12$ & $74 \cdot 4 \pm 24 \cdot 26$ \\
\hline$E R \alpha$ & $0 \cdot 67 \pm 0 \cdot 20$ & $0 \cdot 83 \pm 0 \cdot 04$ & $0 \cdot 46 \pm 0 \cdot 16$ & $0 \cdot 35 \pm 0 \cdot 05$ & $0 \cdot 14 \pm 0 \cdot 01$ & $0.45 \pm 0.06$ \\
\hline$F A B P 3$ & $2 \cdot 09 \pm 0 \cdot 44$ & $2 \cdot 23 \pm 0 \cdot 42$ & $1 \cdot 91 \pm 0 \cdot 29$ & $2 \cdot 43 \pm 0 \cdot 51$ & $1 \cdot 88 \pm 0 \cdot 20$ & $2 \cdot 24 \pm 0 \cdot 45$ \\
\hline GLUT4 & $0 \cdot 05 \pm 0 \cdot 01$ & $0 \cdot 03 \pm 0 \cdot 01$ & $0 \cdot 05 \pm 0 \cdot 01$ & $0 \cdot 03 \pm 0 \cdot 01$ & $0 \cdot 03 \pm 0 \cdot 005$ & $0 \cdot 03 \pm 0 \cdot 01$ \\
\hline IRS1 & $3 \cdot 37 \pm 0 \cdot 32$ & $2 \cdot 43 \pm 0 \cdot 50$ & $3 \cdot 41 \pm 0 \cdot 44$ & $2 \cdot 33 \pm 0 \cdot 32$ & $3 \cdot 52 \pm 0 \cdot 69$ & $4 \cdot 21 \pm 0 \cdot 77$ \\
\hline TBC1D1 & $0 \cdot 74 \pm 0 \cdot 13$ & $0 \cdot 57 \pm 0 \cdot 05$ & $0 \cdot 64 \pm 0.07$ & $0 \cdot 62 \pm 0 \cdot 01$ & $0.63 \pm 0.03$ & $0.71 \pm 0.09$ \\
\hline UCP2 & $25 \cdot 37 \pm 8 \cdot 71$ & $23 \cdot 22 \pm 10 \cdot 33$ & $16 \cdot 42 \pm 7 \cdot 63$ & $5 \cdot 54 \pm 2 \cdot 50$ & $14 \cdot 98 \pm 6 \cdot 22$ & $5 \cdot 75 \pm 3 \cdot 04$ \\
\hline UCP3 & $0.65 \pm 0.06$ & $0 \cdot 54 \pm 0 \cdot 08$ & $0 \cdot 81 \pm 0 \cdot 23$ & $0.44 \pm 0.09$ & $1 \cdot 01 \pm 0 \cdot 03$ & $0 \cdot 57 \pm 0 \cdot 04$ \\
\hline$P G C 1 \alpha$ & $0 \cdot 3 \pm 0 \cdot 06$ & $0 \cdot 20 \pm 0 \cdot 06$ & $0 \cdot 37 \pm 0 \cdot 04$ & $0 \cdot 20 \pm 0 \cdot 10$ & $0 \cdot 27 \pm 0 \cdot 07$ & $0 \cdot 29 \pm 0 \cdot 10$ \\
\hline SRD5A1 & $565 \cdot 79 \pm 90 \cdot 23$ & $491 \cdot 83 \pm 48 \cdot 21$ & $983 \cdot 16 \pm 317 \cdot 22$ & $442 \cdot 01 \pm 37 \cdot 16$ & $667 \cdot 92 \pm 220$ & $427 \cdot 40 \pm 94 \cdot 71$ \\
\hline SREBP1 & $7 \cdot 91 \pm 1 \cdot 89$ & $12 \cdot 58 \pm 1 \cdot 01$ & $8 \cdot 71 \pm 1 \cdot 23$ & $11 \cdot 06 \pm 1 \cdot 2$ & $12 \cdot 12 \pm 1 \cdot 03$ & $12 \cdot 44 \pm 1 \cdot 66$ \\
\hline
\end{tabular}




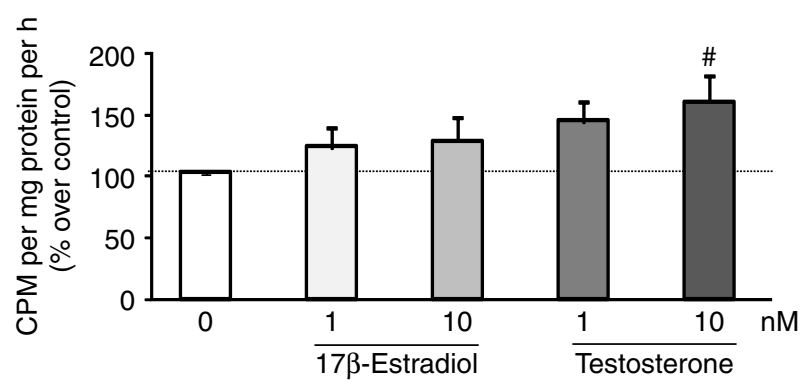

Figure 1 Dose-dependent effects of testosterone or $17 \beta$-estradiol on palmitate oxidation. Myotubes were treated for 4 days with or without $0(0 \cdot 1 \%$ ethanol), 1 , and $10 \mathrm{nM}$ testosterone, or $0(0 \cdot 1 \%$ ethanol), 1, and $10 \mathrm{nME}_{2}$. Results are expressed as mean \pm s.E.M. for myotubes derived from six subjects; three male and three female. ${ }^{\sharp} P<0 \cdot 05$, basal sex hormone treatment versus basal control.

myotubes were cultured in $2 \%$ charcoal/dextran-treated FBS during sex hormone treatment. At baseline, the media supplemented with $2 \%$ charcoal/dextran-treated FBS showed no further changes on myotube differentiation when compared with myotubes differentiated at the presence of $2 \%$ normal FBS, as assessed by phenotypic changes after staining with Wright-Giemsa or by GLUT4 mRNA expression levels (data not shown). Moreover, the mRNA expression of GLUT4 was similar in myotubes exposed to $10 \mathrm{nM}$ testosterone or $\mathrm{E}_{2}$, when compared with the control group for 4 days (Table 1 ).

\section{Dose-response of sex hormone exposure on lipid metabolism}

To explore the effects of hormone treatment on lipid oxidation, human skeletal muscle cells obtained from female and male donors were differentiated for 3 days and exposed, thereafter to 0,1 , and $10 \mathrm{nM}$ testosterone or $\mathrm{E}_{2}$ for 4 days, and palmitate oxidation was assessed. It was found that $10 \mathrm{nM}$ testosterone treatment significantly increased palmitate oxidation. No effects of $\mathrm{E}_{2}$ treatment on palmitate oxidation were observed (Fig. 1). However, $10 \mathrm{nM} \mathrm{E} \mathrm{E}_{2}$ treatment enhanced palmitate oxidation in cells derived from male donors (Fig. 2). Therefore, $10 \mathrm{nM}$ of sex hormones were chosen for further experiments.

\section{Sex hormone-mediated effects on palmitate oxidation}

To determine whether sex hormones differentially influence lipid metabolism in human myotubes derived from male or female donors, basal and insulin-stimulated palmitate oxidation were assayed following 4 days of hormone treatment. Testosterone treatment enhanced basal palmitate oxidation by 82 and $98 \%(P<0 \cdot 05)$ in myotubes from female and male donors respectively (Fig. 2). Treatment with testosterone also enhanced insulin-mediated inhibition of palmitate oxidation by $20 \%(P<0.05)$ in myotubes from male donors. Conversely, $\mathrm{E}_{2}$ treatment enhanced basal palmitate oxidation in myotubes from male donors and decreased insulin action on palmitate oxidation by $45 \%(P<0 \cdot 05)$ in myotubes derived from female donors (Fig. 2).

Effect of testosterone treatment on palmitate oxidation is mediated by classical nuclear receptor

To determine the molecular mechanism of testosterone effect on palmitate oxidation, we investigated whether this effect is mediated by classical nuclear receptor, using the specific sex hormone receptor antagonist, CDX, at the final concentration of $10 \mathrm{nM}$. CDX did not affect basal palmitate oxidation in human myotubes, and the testosterone-mediated increase in palmitate oxidation was abolished in the presence of $10 \mathrm{nM}$ CDX (Fig. 3).

Testosterone or $E_{2}$ treatment enhances insulin-stimulated glucose incorporation into glycogen in cells derived from female donors

To explore the effects of sex hormones on glucose metabolism in human myotubes derived from male or female donors, the basal and insulin-stimulated rates of glucose incorporation into glycogen were measured following hormone treatment. Testosterone treatment enhanced insulin-stimulated glucose incorporation into glycogen by $60 \%(P<0.05)$ in myotubes derived from female donors (Fig. 4). Conversely, testosterone treatment did not alter insulin-stimulated glucose incorporation into glycogen in myotubes derived from male donors (Fig. 4). Moreover, $E_{2}$ treatment also increased insulinstimulated glucose incorporation into glycogen in human myotubes derived from female donors. Overall, a strong sexdependent response is observed in glucose incorporation to glycogen in response to hormone treatment.

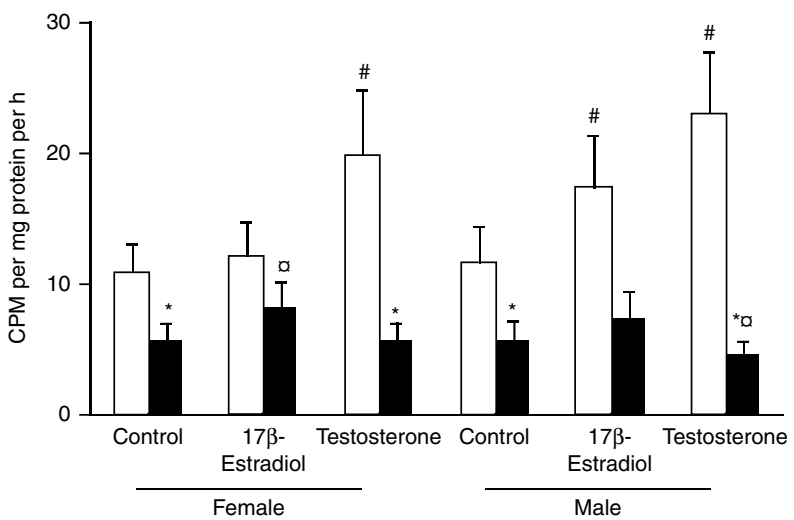

Figure 2 Palmitate oxidation. Myotubes were treated for 4 days with or without $10 \mathrm{nM}$ testosterone or $10 \mathrm{nM} 17 \beta$-estradiol in the absence (white bar) or presence (black bar) of $120 \mathrm{nM}$ insulin. Results are expressed as mean \pm S.E.M. for myotubes derived from female $n=7$ and male $n=7$ donors. ${ }^{a} P<0 \cdot 05$, sex hormone treatment with insulin versus control with insulin; ${ }^{\sharp} P<0 \cdot 05$, basal sex hormone treatment versus basal control; ${ }^{*} P<0 \cdot 05$, insulin versus basal in each condition. 


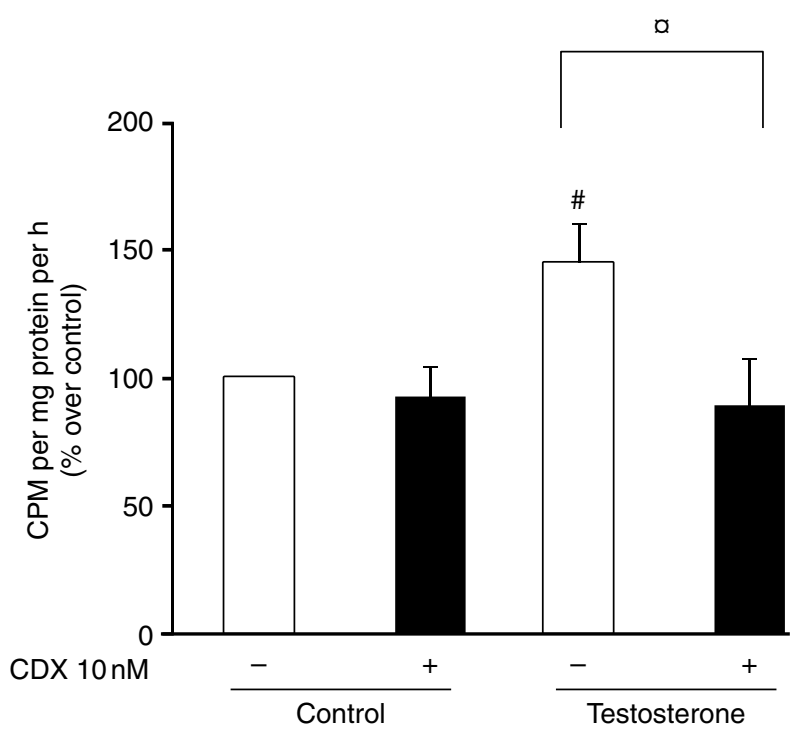

Figure 3 Effect of steroid receptor antagonist on testosteronemediated palmitate oxidation: myotubes were treated for 4 days with $10 \mathrm{nM}$ testosterone with (black bar) or without (white bar) $10 \mathrm{nM}$ CDX (three males and three females). Results are expressed as mean \pm s.E.M., $n=6 .{ }^{a} P<0 \cdot 05$ testosterone + CDX versus testosterone $+0 \cdot 1 \%$ DMSO; ${ }^{*} P<0 \cdot 05$, sex hormone treatment versus control $(0 \cdot 1 \%$ ethanol $+0 \cdot 1 \%$ DMSO $)$.

\section{Sex hormone treatment mediates protein phosphorylation}

To investigate the impact of sex hormone treatment on signal transduction in myotubes derived from female and male donors, the level of protein phosphorylation of prominent muscle metabolic signaling factors was assayed under basal and insulin-stimulated conditions following hormone treatment. Testosterone or $\mathrm{E}_{2}$ treatment increased $\mathrm{AKT}^{\mathrm{Ser} 473}$ phosphorylation by 64 and $43 \%(P<0 \cdot 05)$ respectively in myotubes derived from female donors in sex-dependent manner (Fig. 5A). Total AKT protein expression was unaltered.

Testosterone treatment increased $\mathrm{AMPK}^{\mathrm{Thr} 172}$ phosphorylation by $50 \%(P<0 \cdot 05)$ in myotubes from male donors and tended to increase $\mathrm{AMPK}^{\text {Thr172 }}$ phosphorylation in female donors by $49 \%(P=0 \cdot 06$; Fig. 6B). Total AMPK protein expression was unaltered. $E_{2}$ did not alter either $\mathrm{AMPK}^{\mathrm{Thr} 172}$ phosphorylation or protein content in human myotubes (Fig. 6A and B).

Testosterone treatment enhanced basal and insulin-stimulated p38 phosphorylation in myotubes derived from female donors by $309 \%(P<0 \cdot 05)$ and $217 \%(P<0 \cdot 05)$ respectively (Fig. 7A). In myotubes derived from males, basal and insulin-stimulated p38 phosphorylation were enhanced by $198 \%(P<0 \cdot 05)$ and $145 \%(P<0 \cdot 05)$ respectively (Fig. 7B). In contrast, $\mathrm{E}_{2}$ did not alter either p38 phosphorylation or protein content in human myotubes (Fig. 7A and B). Phosphorylation and total protein levels of ERK1/2 MAPK, pIRS1 ${ }^{\mathrm{ser} 636}$, and $\mathrm{p} 70^{\mathrm{s} 6 \mathrm{k}}$ were unaltered after a 4-day exposure to either sex hormone (data not shown).
Differential effects of testosterone and $E_{2}$ on $m R N A$ expression

To determine the influence of sex hormone treatment on mRNA expression of genes involved in lipid and glucose metabolism, human myotubes derived from female or male donors were treated with testosterone or $\mathrm{E}_{2}$ for 4 days and gene expression was determined. The treatment with either hormone had a differential effect on several genes (Table 2). $S H G B$ mRNA expression was increased by $53 \%$ for $\mathrm{E}_{2}$-treated and $60 \%$ for testosterone-treated versus control $(P<0 \cdot 05)$ in myotubes from female donors (Table 2$)$. The mRNA expression of $P D K 4$ was increased with $\mathrm{E}_{2}$ treatment in myotubes from female donors by $123 \%(P<0 \cdot 05$; Table 2$)$. The mRNA level of PDK4 in the estradiol-treated state was significantly higher in myotubes from female donors than in myotubes from male donors, which may indicate a sexdependent response. PPARG gene expression was reduced in cultured cells from female donors by 42 and $41 \%$ in myotubes from male donors for testosterone-treated versus control $(P<0 \cdot 05)$. $\mathrm{E}_{2}$ treatment reduced PPARG mRNA expression by $21 \%$ in myotubes from male donors $(P<0 \cdot 05)$ and showed a tendency to decrease in myotubes from female donors $(P=0 \cdot 08)$. In a sex-dependent manner, the effect of $\mathrm{E}_{2}$ on PPARG expression is significantly higher in myotubes from male donors (Table 2). Treatment with testosterone, but not $\mathrm{E}_{2}$, increased GYS1 mRNA expression by $29 \%(P<0 \cdot 05)$ for testosterone versus control in cultured cells from male subjects (Table 2).

The IRS2 mRNA expression was increased by 233 and $200 \%$ for testosterone-treated versus control $(P<0 \cdot 05)$ in cultured cells from female and male donors respectively. Interestingly, the effect of $\mathrm{E}_{2}$ on IRS2 mRNA expression showed a sex-specific difference (Table 2). PPARD gene

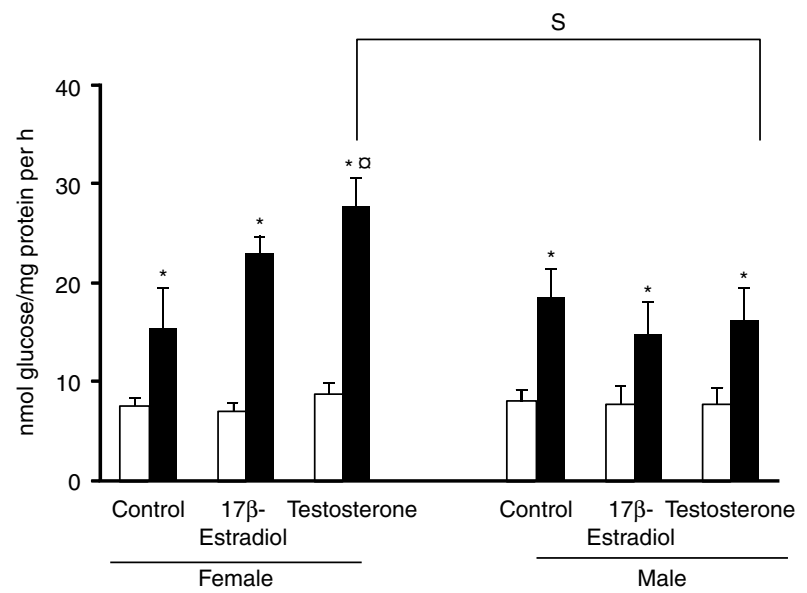

Figure 4 Glucose incorporation into glycogen. Myotubes were treated for 4 days with or without $10 \mathrm{nM}$ testosterone or $10 \mathrm{nM}$ $17 \beta$-estradiol in the absence (white bar) or presence (black bar) of $120 \mathrm{nM}$ insulin. Results are expressed as mean \pm s.E.M. for myotubes derived from female $n=7$ and male $n=7$ donors. ${ }^{a} P<0 \cdot 05$, sex hormone treatment with insulin versus control with insulin and ${ }^{*} P<0 \cdot 05$, insulin versus basal in each group; $S P<0 \cdot 05$, male versus female, indicates sex-specific differences. 

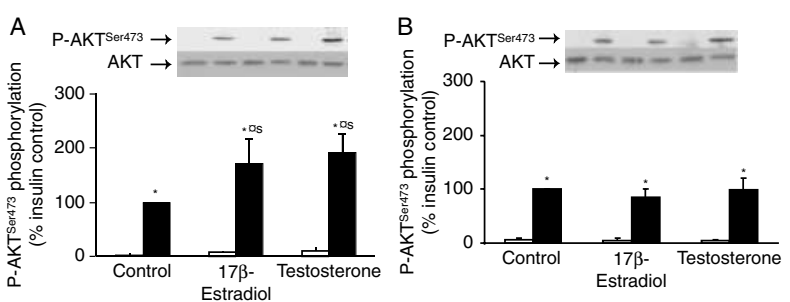

Figure $5 \mathrm{AKT}^{\mathrm{Ser} 473}$ phosphorylation and protein abundance. Myotubes were treated for 4 days with or without $10 \mathrm{nM}$ testosterone or $10 \mathrm{nM} 17 \beta$-estradiol in the absence (white bar) or presence (black bar) of $120 \mathrm{nM}$ insulin. AKT ${ }^{\text {Ser473 }}$ phosphorylation and protein expression were measured in myotubes derived from female $(\mathrm{A} ; n=7)$ or male $(\mathrm{B} ; n=7)$ donors. Results are expressed as mean \pm S.E.M. ${ }^{a} P<0 \cdot 05$, sex hormone treatment with insulin versus control with insulin; ${ }^{*} P<0 \cdot 05$, insulin versus basal in each condition; $S P<0 \cdot 05$, male versus female, indicates sex-specific differences.

expression was increased by $16 \cdot 5 \%$ with $\mathrm{E}_{2}$ treatment versus control $(P<0 \cdot 05$; Table 2). Moreover, PPARD mRNA level showed a significant sex-related difference, with a higher expression pattern in myotubes from female donors than from male donors in the control group.

Exposure of either sex hormone reduced the mRNA expression of $A R$ by 43 and $50 \%$ for $\mathrm{E}_{2}$ and testosterone treatment versus control respectively in myotubes from male donors $(P<0 \cdot 05)$. In addition, the mRNA expression of $A R$ is significantly higher in myotubes from male donors when compared with myotubes from female donors. The CPT1 mRNA expression showed a sex-dependent expression pattern, as higher expression was observed in myotubes from male donors than from female donors in the control group $(P<0 \cdot 05$; Table 2$)$. The mRNA expression of $S C D$, in a sex-dependent manner, was significantly lower in myotubes obtained from female donors than from male donors in the control group (Table 2). Several other metabolic genes were also analyzed and were not altered by either $E_{2}$ or testosterone treatment (Table 1). The mRNA expression of P450arom, ER $\beta$, and SRD5A2 was undetectable in human myotubes.

\section{Discussion}

Androgen deficiency syndromes and hypogonadism, clinical conditions characterized by a deregulation of sex hormones, are associated with aging, obesity, type 2 diabetes, and cardiovascular disease (Soler et al. 1989, Haffner et al. 1996, Stellato et al. 2000, Oh et al. 2002, Farrell et al. 2008, Traish et al. 2009). We tested the hypothesis that testosterone or $E_{2}$ sex hormone treatment plays an important role in metabolism in primary skeletal muscle cells, and that an intrinsic sex difference may become apparent following exogenous sex hormone exposure on metabolism.

In this study, we show evidence that both testosterone and $\mathrm{E}_{2}$ play a role in glucose and lipid metabolism, and intrinsic sex differences in metabolism may reveal after sex hormone exposure in human skeletal muscle cell. There is much evidence showing that estradiol plays a role in regulating substrate metabolism, and it had been shown that treatment with estradiol in young men increased skeletal muscle $\beta$-oxidation capacity (Maher et al. 2010a). Consistent with this, we have observed an enhanced palmitate oxidation mediated by $E_{2}$ in myotubes from male donors only, while testosterone exposure enhanced palmitate oxidation in myotubes obtained from both sexes. The effect of testosterone on lipid oxidation occurred in concordance with increased $\mathrm{AMPK}^{\text {Thr172 }}$ phosphorylation, a key factor in the regulation of lipid metabolism (Hardie 2004). IRS2 is also an important regulator of skeletal muscle lipid metabolism in cultured myotubes (Bouzakri et al. 2006), and in this study, we demonstrate that the IRS 2 mRNA expression was increased in response to testosterone treatment in both female and male donors, which may explain the enhanced fatty acid oxidation. In addition, administration of testosterone in elderly men has shown to increase muscle mass and muscle strength in a dosedependent relationship (Storer et al. 2008) which may indicate the important role of testosterone in metabolism and muscle growth (Wolfe et al. 2000). However, any clear changes in the skeletal muscle growth and differentiation were not found in this study.

To investigate the molecular mechanism of testosterone effect on lipid oxidation, we exposed cultured myotubes to the specific AR antagonist, CDX. This inhibitor has been used in cancer research in breast or prostate cancer (Bhattacharyya et al. 2006, Auricchio et al. 2008). Moreover, sex hormone receptor inhibitors have been used to investigate the molecular mechanism of sex hormone action in skeletal muscle (Inoue et al. 1994). Interestingly, we show that the positive effect of testosterone on palmitate oxidation was abolished at the presence of the AR antagonist (CDX). This effect may indicate that testosterone-enhanced palmitate oxidation is via the classical steroid receptor. However, the effect of $E_{2}$ differs between female and male subjects, and further investigation is warranted to determine the cause of sex-related differences on estradiol-mediated palmitate oxidation.
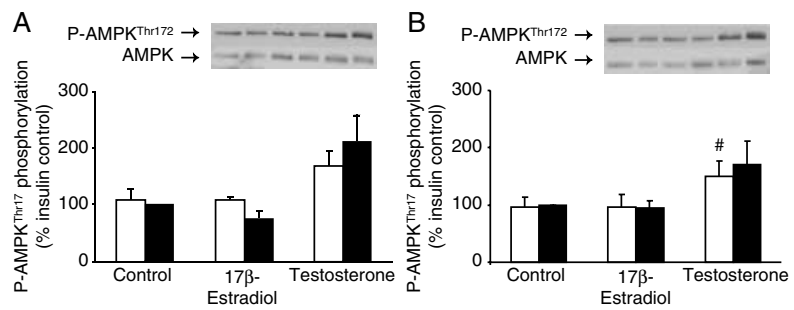

Figure $6 \mathrm{AMPK}^{\mathrm{Th} 172}$ phosphorylation and protein abundance. Myotubes were treated for 4 days with or without $10 \mathrm{nM}$ testosterone or $10 \mathrm{nM} 17 \beta$-estradiol in the absence (white bar) or presence (black bar) of $120 \mathrm{nM}$ insulin. AMPK ${ }^{\mathrm{Thr} 172}$ phosphorylation and protein expression were determined in myotubes derived from female $(\mathrm{A} ; n=7-9)$ or male $(\mathrm{B} ; n=7-9)$ donors. Results are expressed as mean \pm s.E.M. ${ }^{\#} P<0 \cdot 05$, hormone treatment versus basal control. 

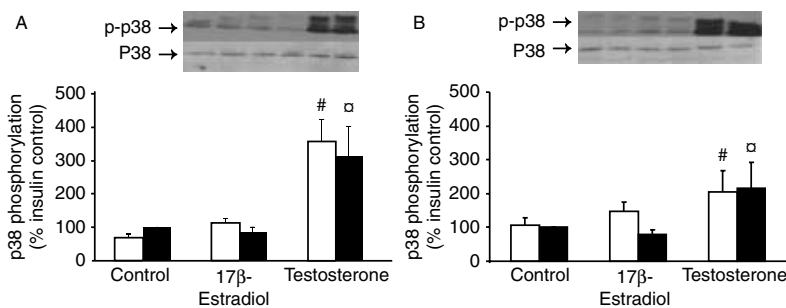

Figure 7 p38 phosphorylation and protein abundance. Myotubes were treated for 4 days with or without $10 \mathrm{nM}$ testosterone or $10 \mathrm{nM}$ $17 \beta$-estradiol in the absence (white bar) or presence (black bar) of $120 \mathrm{nM}$ insulin. p38 phosphorylation and protein abundance in myotubes derived from female $(\mathrm{A} ; n=7-8)$ or male $(\mathrm{B} ; n=7-8)$ donors. Results are expressed as mean \pm s.E.M. ${ }^{a} P<0 \cdot 05$, sex hormone treatment with insulin versus control with insulin; ${ }^{\#} P<0 \cdot 05$, hormone treatment versus basal control.

Previous studies provide evidence for a pivotal role of testosterone in skeletal muscle glucose metabolism. Testosterone treatment increased glycogen content in extensor digitorum longus and soleus muscles of hyperglycemic sedentary female rats (Ramamani et al. 1999, van Breda et al. 2003). In this study, treatment with either hormone increased insulin-stimulated glucose incorporation into glycogen and phosphorylation of $\mathrm{AKT}^{\mathrm{Ser} 473}$ in myotubes from female donors only. This may indicate a specific sexrelated role of sex hormones on glucose storage via insulin action in skeletal muscle cells.

Testosterone treatment of skeletal muscle cells triggered the activation of known signaling factors such as p38 MAPK, which is associated with insulin resistance (Liu \& Cao 2009). Although enhanced p38 activation may suggest a direct link to insulin resistance in skeletal muscle cells, our data do not provide evidence for any impairment in the insulin response. Rather we found that testosterone treatment enhances insulin-stimulated glucose incorporation into glycogen in myotubes derived from female donors. Interestingly, a p38 MAPK inhibitor prevents glucose transport in 3T3 L1 adipocytes and L6 muscle cell cultures (Sweeney et al. 1999), which may suggest an important positive role of $\mathrm{p} 38$ MAPK in glucose transport. This may partly support our findings that enhanced p38 phosphorylation after testosterone treatment may have a positive effect on glucose incorporation into glycogen. However, this effect is not found on the basal or insulin-stimulated level of testosterone in the myotubes obtained from male donors. Thus, the role for testosterone inducing p38 phosphorylation requires further investigation.

Sex hormone binding globulin (SHBG) mRNA expression was detected in human skeletal muscle myotubes, but its function has not previously been evaluated in myotubes. SHBG is produced in the liver, brain, uterus, placenta, and testes (Hammond \& Bocchinfuso 1996), based on the present observations, in human cultured skeletal muscle. Interestingly, the upregulation of the SHBG mRNA expression after the exposure with either sex hormone was only found in myotubes from female subjects. This effect of testosterone is in accordance with earlier results, whereby treatment with $10 \mathrm{nM}$ testosterone increased the intraand extracellular SHBG content in HepG2 cell cultures (Loukovaara et al. 1995).

We were unable to obtain any differences or changes in the ER mRNA expression levels, while the mRNA expression of the AR was higher in myotubes from male donors at baseline in a sex-dependent manner, and the expression was decreased after the exposure to either sex hormone. It is well established that $\mathrm{AR}$ and ER expression are sensitive to circulating hormones in vivo (Baltgalvis et al. 2010). In a study done on stromal cells, estradiol reduced the expression of both AR and ER (Smith et al. 2002), in line with our finding on the $A R$ mRNA expression, but differs with the ER mRNA expression data, which was not altered after sex hormone treatment or between sexes. In addition, AR expression was increased after chronic testosterone treatment in a C2C12 skeletal muscle cell line and during differentiation (Wannenes et al. 2008), and this effect was also observed in mesenchymal,

Table 2 Differential mRNA expression of metabolic genes assessed in myotubes from female and male donors after sex hormone exposure. Myotubes were treated with vehicle as control $(0 \cdot 1 \%$ ethanol), $10 \mathrm{nM} 17 \beta$-estradiol, or testosterone for 4 days. Results are mean \pm s.E.M. for $n=7$ female subjects and $n=7$ male subjects. Results were normalized to $18 \mathrm{~s}$ RNA, and all the values are multiplied by $10^{-6}$

Control

$$
\text { Female }
$$

Genes

$A R$

CPT1

GYS1

IRS2

PDK4

PPARD

PPARG

$S H G B$

$S C D$
$17 \beta$-Estradiol

\begin{tabular}{l} 
Female \\
\hline \\
$0 \cdot 66 \pm 0 \cdot 02$ \\
$0 \cdot 1 \pm 0 \cdot 01$ \\
$16 \cdot 59 \pm 1 \cdot 08$ \\
${ }^{*} 0 \cdot 06 \pm 0 \cdot 01$ \\
${ }^{*}+1 \cdot 03 \pm 0 \cdot 21$ \\
${ }^{+} 86 \cdot 38 \pm 10 \cdot 12$ \\
${ }^{*} 14 \cdot 86 \pm 1 \cdot 38$ \\
${ }^{+} 0 \cdot 23 \pm 0 \cdot 04$ \\
$101 \cdot 36 \pm 5 \cdot 75$
\end{tabular}

Testosterone

\begin{tabular}{|c|c|}
\hline Male & Female \\
\hline${ }^{+} 1 \cdot 02 \pm 0 \cdot 23$ & $0 \cdot 48 \pm 0 \cdot 07$ \\
\hline $0.09 \pm 0.004$ & ${ }^{*} 0 \cdot 14 \pm 0 \cdot 01$ \\
\hline $18 \cdot 42 \pm 2 \cdot 85$ & $18 \cdot 28 \pm 0 \cdot 87$ \\
\hline$* 0 \cdot 02 \pm 0.003$ & ${ }^{\ddagger} 0 \cdot 10 \pm 0 \cdot 02$ \\
\hline$* 0 \cdot 57 \pm 0.13$ & $0 \cdot 68 \pm 0 \cdot 15$ \\
\hline $62 \cdot 30 \pm 3 \cdot 7$ & $75 \cdot 98 \pm 4 \cdot 82$ \\
\hline${ }^{*}{ }^{+} 40 \cdot 78 \pm 7 \cdot 02$ & ${ }^{\ddagger} 16.08 \pm 1.06$ \\
\hline $0.24 \pm 0.03$ & ${ }^{\ddagger} 0 \cdot 24 \pm 0 \cdot 04$ \\
\hline $154 \cdot 76 \pm 24 \cdot 77$ & $160 \cdot 05 \pm 2 \cdot 23$ \\
\hline
\end{tabular}

Male

${ }^{\ddagger} 0 \cdot 89 \pm 0.03$

$* 0.07 \pm 0.01$

${ }^{*} 22.07 \pm 3.79$

${ }^{\ddagger} 0.09 \pm 0.02$

$0 \cdot 53 \pm 0 \cdot 10$

$65 \cdot 10 \pm 11 \cdot 24$

${ }^{\ddagger} 30 \cdot 47 \pm 6 \cdot 4$

$0 \cdot 20 \pm 0.01$

$179 \cdot 71 \pm 46 \cdot 65$

${ }^{*} P<0 \cdot 05$, male versus female per condition and indicates the sex-specific differences; ${ }^{\dagger} P<0 \cdot 05,17 \beta$-estradiol treatment versus control; ${ }^{\ddagger} P<0 \cdot 005$, testosterone treatment versus control. 
pluripotent cell line after exposure to testosterone (Singh et al. 2003). However, our finding may indicate a negative feedback loop of chronic testosterone exposure on its own receptor in human myotubes.

Interestingly, we have previously reported that the sex of the donor does not influence glucose and lipid metabolism in human myotubes in steroid hormone-free media, with evidence against 'metabolic memory' of the external factors such as hormones and cytokines known to influence glucose and lipid metabolism in cell cultures grown in vitro (Rune et al. 2009). However, we previously observed a trend towards a sex dependency in the mRNA expression of some genes such as PPARG at basal, hence our earlier study was likely underpowered to detect the previous data. However, in this study, significant sex differences in baseline mRNA expression of CPT1, PPARD, PPARG, and SCD were shown. Interestingly, in line with our findings, there is evidence showing that the mRNA of CPT1 and PPARD was higher in skeletal muscle biopsies from young women, when compared with men (for review, Maher et al. (2010b)). These data may indicate that women in comparison with men have greater capacity for fatty acid metabolism in skeletal muscle. Moreover, a sex difference was observed at the mRNA level of IRS2 and $P D K 4$ after $\mathrm{E}_{2}$ treatment, where it was higher in myotubes from female donors when compared with male donors.

Our data showed a clear effect of either hormone on the mRNA expression of several proteins involved in glucose metabolism such as GYS1 and PDK4 or lipid metabolism PPARD, PPARG, and IRS2. In addition to an involvement in the regulation of glucose metabolism (Rosa et al. 2003, Wende et al. 2005), PDK4 plays an important role in lipid metabolism (Rosa et al. 2003), and it is also known to be regulated by pyruvate production. It has been shown previously that PDK4 activity is enhanced at high rates of fatty acid oxidation, which causes a consequent inhibitory effect on glucose oxidation (for review, Sugden \& Holness (2006)). Consistent to our mRNA expression data, $E_{2}$ treatment increased $P D K 4$ gene expression in ovariectomized female rats, (Campbell et al. 2003), suggesting a regulative role of $E_{2}$ in skeletal muscle lipid metabolism. In contrast to this, our data showed that $E_{2}$ treatment-mediated fatty acid oxidation was only observed in myotubes from male donors and not in the female donors. Whether PDK4 is directly involved in skeletal muscle cell palmitate oxidation or insulinstimulated glucose incorporation into glycogen after sex hormone exposure remains to be investigated.

PPARG is a gene involved in lipid metabolism (reviewed in Zhang et al. (2004) and Jay \& Ren (2007), and our data regarding the effect of testosterone on PPARG mRNA expression is similar to earlier findings in rat primary neuronal cultured cells, where testosterone treatment inhibited PPARG activity and fat mass control (Du et al. 2009). We have also found a sex difference of PPARG mRNA expression at baseline. Whether the downregulation of the PPARG gene observed in this study is due to a negative feedback in response to sex hormone treatment is unknown. Thus, our current data suggest a 'sex memory' at the level of mRNA, which is further pronounced following exposure to sex hormones.

Nevertheless, the mRNA expression of several genes crucial to lipid oxidation (UCP2, UCP3, FABP3, PGC1alpha and $S R E B P$ ) was unaltered in control or sex hormone-treated myotubes from female and male donors. The mRNA expression of several regulatory genes involved in glucose metabolism such as the TBC1D1, GLUT4 and IRS1, was not changed after sex hormone treatment or between sexes. However, many of these genes such as SREBP (Simpson \& McInnes 2005) and GLUT4 (Muthusamy et al. 2009) were shown by others to be regulated by either testosterone or $E_{2}$.

We have investigated whether testosterone can be aromatized to $\mathrm{E}_{2}$ via the P450arom or into its 'bioactive' metabolite dihydrotestosterone, DHT, via the 5-alpha reductase $S R D 5 A 1$ and $S R D 5 A 2$, and our data show an almost undetectable P450arom and SRD5A2 mRNA expressions, but a clear mRNA expression of $S R D 5 A 1$ was found in human myotubes, which may speculate a local effect of the DHT on skeletal muscle metabolism.

In summary, testosterone and $\mathrm{E}_{2}$ have differential effects on the regulation of glucose and lipid metabolism in human skeletal muscle cells. This is clear through observed changes in gene expression and metabolic readouts. Testosterone and $\mathrm{E}_{2}$ treatment enhanced glucose incorporation to glycogen via increased insulin-stimulated $\mathrm{AKT}^{\mathrm{Ser} 473}$ in a sex-dependent difference. Moreover, treatment with testosterone increased palmitate oxidation in cultured myotubes derived from female and male donors, which is potentially mediated via classical nuclear sex hormone receptors. Taken together, our data suggest that testosterone and $\mathrm{E}_{2}$ exert differential metabolic outcomes in a sex-dependent manner, and this intrinsic sex hormone-specific difference is maintained in cultured myotubes and consequently uncovered by exogenous sex hormone exposure.

\section{Declaration of interest}

The authors declare that there is no conflict of interest that could be perceived as prejudicing the impartiality of the research reported.

\section{Funding}

This work was supported by grants from Karolinska Institutet, Novo Nordisk Foundation, Center for Gender Medicine at Karolinska Institutet, the Swedish Research Council, the Swedish Society of Medicine, Åke-Wiberg Foundation, Magnus Bergvalls Foundation, Fredrik and Ingrid Thurings Foundation, Knut and Alice Wallenberg Foundation (2005.0120), and the European Union Framework 6 Network of Excellence EUGENE2 no. LSHM-CT-2004-512013.

\section{Acknowledgements}

We thank Prof. Juleen Zierath and Prof. Anna Krook for critical discussion during manuscript preparation. We thank Ms Eva Palmer for excellent technical assistance. 


\section{References}

Abate N, Haffner SM, Garg A, Peshock RM \& Grundy SM 2002 Sex steroid hormones, upper body obesity, and insulin resistance. Journal of Clinical Endocrinology and Metabolism 87 4522-4527. (doi:10.1210/jc.2002-020567)

Al-Khalili F, Eriksson M, Landgren BM \& Schenck-Gustafsson K 1998 Effect of conjugated estrogen on peripheral flow-mediated vasodilation in postmenopausal women. American Journal of Cardiology 82 215-218. (doi:10. 1016/S0002-9149(98)00314-2)

Al-Khalili L, Chibalin AV, Kannisto K, Zhang BB, Permert J, Holman GD, Ehrenborg E, Ding VD, Zierath JR \& Krook A 2003 Insulin action in cultured human skeletal muscle cells during differentiation: assessment of cell surface GLUT4 and GLUT1 content. Cellular and Molecular Life Sciences 60 991-998. (doi:10.1007/s00018-003-3001-3)

Al-Khalili L, Kramer D, Wretenberg P \& Krook A 2004 Human skeletal muscle cell differentiation is associated with changes in myogenic markers and enhanced insulin-mediated MAPK and PKB phosphorylation. Acta Physiologica Scandinavica 180 395-403. (doi:10.1111/j.1365-201X.2004. 01259.x)

Al-Khalili L, Bouzakri K, Glund S, Lonnqvist F, Koistinen HA \& Krook A 2006 Signaling specificity of interleukin-6 action on glucose and lipid metabolism in skeletal muscle. Molecular Endocrinology 20 3364-3375. (doi:10.1210/me.2005-0490)

Andersson B, Mattsson L-A, Hahn L, Lapidus L, Holm G, Bengtsson B-A \& Bjorntorp P 1997 Estrogen replacement therapy decreases hyperandrogenicity and improves glucose homeostasis and plasma lipids in postmenopausal women with noninsulin-dependent diabetes mellitus. Journal of Clinical Endocrinology and Metabolism 82 638-643. (doi:10.1210/jc. 82.2.638)

Auricchio F, Migliaccio A \& Castoria G 2008 Sex-steroid hormones and EGF signalling in breast and prostate cancer cells: targeting the association of $\mathrm{Src}$ with steroid receptors. Steroids 73 880-884. (doi:10.1016/j.steroids.2008. 01.023)

Baltgalvis KA, Greising SM, Warren GL \& Lowe DA 2010 Estrogen regulates estrogen receptors and antioxidant gene expression in mouse skeletal muscle. PLOS ONE 5 e10164. (doi:10.1371/journal.pone.0010164)

van den Beld AW, de Jong FH, Grobbee DE, Pols HAP \& Lamberts SWJ 2000 Measures of bioavailable serum testosterone and estradiol and their relationships with muscle strength, bone density, and body composition in elderly men. Journal of Clinical Endocrinology and Metabolism 85 3276-3282. (doi:10.1210/jc.85.9.3276)

Bhattacharyya RS, Krishnan AV, Swami S \& Feldman D 2006 Fulvestrant (ICI 182,780) down-regulates androgen receptor expression and diminishes androgenic responses in LNCaP human prostate cancer cells. Molecular Cancer Therapeutics 5 1539-1549. (doi:10.1158/1535-7163.MCT-06-0065)

Bouzakri K, Zachrisson A, Al-Khalili L, Zhang BB, Koistinen HA, Krook A \& Zierath JR 2006 siRNA-based gene silencing reveals specialized roles of IRS-1/Akt2 and IRS-2/Akt1 in glucose and lipid metabolism in human skeletal muscle. Cell Metabolism 4 89-96. (doi:10.1016/j.cmet.2006.04.008)

van Breda E, Keizer H, Kuipers H \& Kranenburg G 2003 Effect of testosterone and endurance training on glycogen metabolism in skeletal muscle of chronic hyperglycaemic female rats. British Journal of Sports Medicine 37 345-350. (doi:10.1136/bjsm.37.4.345)

Campbell SE \& Febbraio MA 2001 Effect of ovarian hormones on mitochondrial enzyme activity in the fat oxidation pathway of skeletal muscle. American Journal of Physiology. Endocrinology and Metabolism 281 E803-E808.

Campbell SE, Mehan KA, Tunstall RJ, Febbraio MA \& Cameron-Smith D 2003 17beta-Estradiol upregulates the expression of peroxisome proliferator-activated receptor alpha and lipid oxidative genes in skeletal muscle. Journal of Molecular Endocrinology 31 37-45. (doi:10.1677/jme.0.0310037)

Casey RW \& Barkin J 2008 Testosterone replacement therapy for the primary care physician. Canadian Journal of Urology 15 (Supplement 1) 71-77 (discussion 77).

D'Eon TM, Souza SC, Aronovitz M, Obin MS, Fried SK \& Greenberg AS 2005 Estrogen regulation of adiposity and fuel partitioning. Evidence of genomic and non-genomic regulation of lipogenic and oxidative pathways. Journal of Biological Chemistry 280 35983-35991. (doi:10.1074/jbc. M507339200)

Du J, Zhang L \& Wang Z 2009 Testosterone inhibits the activity of peroxisome proliferator-activated receptor gamma in a transcriptional transaction assay. Die Pharmazie 64 692-693.

Dubey RK \& Jackson EK 2001 Cardiovascular protective effects of 17betaestradiol metabolites. Journal of Applied Physiology 91 1868-1883.

Farrell JB, Deshmukh A \& Baghaie AA 2008 Low testosterone and the association with type 2 diabetes. Diabetes Educator 34 799-806. (doi:10. $1177 / 0145721708323100)$

Godsland IF 2001 Effects of postmenopausal hormone replacement therapy on lipid, lipoprotein, and apolipoprotein (a) concentrations: analysis of studies published from 1974-2000. Fertility and Sterility 75 898-915. (doi:10.1016/ S0015-0282(01)01699-5)

Grossmann M, Gianatti EJ \& Zajac JD 2010 Testosterone and type 2 diabetes. Current Opinion in Endocrinology, Diabetes, and Obesity 17 247-256. (doi:10. 1097/MED.0b013e32833919cf)

Haffner SM 2000 Sex hormones, obesity, fat distribution, type 2 diabetes and insulin resistance: epidemiological and clinical correlation. International Journal of Obesity and Related Metabolic Disorders 24 (Supplement 2) S56-S58.

Haffner SM, Valdez RA, Mykkanen L, Stern MP \& Katz MS 1994 Decreased testosterone and dehydroepiandrosterone sulfate concentrations are associated with increased insulin and glucose concentrations in nondiabetic men. Metabolism 43 599-603. (doi:10.1016/0026-0495(94)90202-X)

Haffner SM, Shaten J, Stern MP, Smith GD \& Kuller L 1996 Low levels of sex hormone-binding globulin and testosterone predict the development of non-insulin-dependent diabetes mellitus in men. MRFIT Research Group. Multiple Risk Factor Intervention Trial. American Journal of Epidemiology 143 889-897.

Hammond GL \& Bocchinfuso WP 1996 Sex hormone-binding globulin: gene organization and structure/function analyses. Hormone Research $\mathbf{4 5}$ 197-201. (doi:10.1159/000184787)

Hardie DG 2004 AMP-activated protein kinase: a master switch in glucose and lipid metabolism. Reviews in Endocrine and Metabolic Disorders 5 119-125. (doi:10.1023/B:REMD.0000021433.63915.bb)

Inoue K, Yamasaki S, Fushiki T, Okada Y \& Sugimoto E 1994 Androgen receptor antagonist suppresses exercise-induced hypertrophy of skeletal muscle. European Journal of Applied Physiology and Occupational Physiology 69 88-91. (doi:10.1007/BF00867933)

Jay MA \& Ren J 2007 Peroxisome proliferator-activated receptor (PPAR) in metabolic syndrome and type 2 diabetes mellitus. Current Diabetes Reviews 3 33-39. (doi:10.2174/157339907779802067)

Liu Z \& Cao W 2009 p38 mitogen-activated protein kinase: a critical node linking insulin resistance and cardiovascular diseases in type 2 diabetes mellitus. Endocrine, Metabolic and Immune Disorders Drug Targets 9 38-46. (doi:10.2174/187153009787582397)

Lobo RA 2008 Metabolic syndrome after menopause and the role of hormones. Maturitas 60 10-18. (doi:10.1016/j.maturitas.2008.02.008)

Loukovaara M, Carson M \& Adlercreutz H 1995 Regulation of production and secretion of sex hormone-binding globulin in HepG2 cell cultures by hormones and growth factors. Journal of Clinical Endocrinology and Metabolism 80 160-164. (doi:10.1210/jc.80.1.160)

Maher AC, Akhtar M \& Tarnopolsky MA 2010a Men supplemented with 17beta-estradiol have increased beta-oxidation capacity in skeletal muscle Physiological Genomics 42 342-347. (doi:10.1152/physiolgenomics.00016. 2010)

Maher AC, Akhtar M, Vockley J \& Tarnopolsky MA 2010b Women have higher protein content of beta-oxidation enzymes in skeletal muscle than men. PLoS ONE 5 e12025. (doi:10.1371/journal.pone.0012025)

Marin P, Krotkiewski M \& Bjorntorp P 1992 Androgen treatment of middleaged, obese men: effects on metabolism, muscle and adipose tissues. European Journal of Medicine 1 329-336.

Mercuro G, Zoncu S \& Dragoni F 2003 Gender differences in cardiovascular risk factors. Italian Heart Journal 4 363-366.

Miner M, Canty DJ \& Shabsigh R 2008 Testosterone replacement therapy in hypogonadal men: assessing benefits, risks, and best practices. Postgraduate Medicine 120 130-153. (doi:10.3810/pgm.2008.09.1914) 
Murphy E \& Steenbergen C 2007 Gender-based differences in mechanisms of protection in myocardial ischemia-reperfusion injury. Cardiovascular Research 75 478-486. (doi:10.1016/j.cardiores.2007.03.025)

Muthusamy T, Murugesan P \& Balasubramanian K 2009 Sex steroids deficiency impairs glucose transporter 4 expression and its translocation through defective Akt phosphorylation in target tissues of adult male rat. Metabolism 58 1581-1592. (doi:10.1016/j.metabol.2009.05.010)

Oh JY, Barrett-Connor E, Wedick NM \& Wingard DL 2002 Endogenous sex hormones and the development of type 2 diabetes in older men and women: the Rancho Bernardo study. Diabetes Care 25 55-60. (doi:10. 2337/diacare.25.1.55)

Polotsky HN \& Polotsky AJ 2010 Metabolic implications of menopause. Seminars in Reproductive Medicine 28 426-434. (doi:10.1055/s-00301262902)

Poole CN, Roberts MD, Dalbo VJ, Sunderland KL \& Kerksick CM 2011 Megalin and androgen receptor gene expression in young and old human skeletal muscle before and after three sequential exercise bouts. Journal of Strength and Conditioning Research 25 309-317. (doi:10.1519/JSC. Ob013e318202e45d)

Ramamani A, Aruldhas MM \& Govindarajulu P 1999 Differential response of rat skeletal muscle glycogen metabolism to testosterone and estradiol. Canadian Journal of Physiology and Pharmacology 77 300-304. (doi:10.1139/ y99-016)

Regitz-Zagrosek V, Lehmkuhl E \& Mahmoodzadeh S 2007 Gender aspects of the role of the metabolic syndrome as a risk factor for cardiovascular disease. Gender Medicine 4 (Supplement B) S162-S177. (doi:10.1016/ S1550-8579(07)80056-8)

Roepstorff C, Steffensen CH, Madsen M, Stallknecht B, Kanstrup IL, Richter EA \& Kiens B 2002 Gender differences in substrate utilization during submaximal exercise in endurance-trained subjects. American Journal of Physiology. Endocrinology and Metabolism 282 E435-E447.

Rosa G, Di Rocco P, Manco M, Greco AV, Castagneto M, Vidal H \& Mingrone G 2003 Reduced PDK4 expression associates with increased insulin sensitivity in postobese patients. Obesity Research 11 176-182. (doi:10.1038/oby.2003.28)

Rune A, Salehzadeh F, Szekeres F, Kuhn I, Osler ME \& Al-Khalili L 2009 Evidence against a sexual dimorphism in glucose and fatty acid metabolism in skeletal muscle cultures from age-matched men and post-menopausal women. Acta Physiologica 197 207-215. (doi:10.1111/j.1748-1716.2009. 02010.x)

Salpeter SR, Walsh JM, Ormiston TM, Greyber E, Buckley NS \& Salpeter EE 2006 Meta-analysis: effect of hormone-replacement therapy on components of the metabolic syndrome in postmenopausal women. Diabetes, Obesity and Metabolism 8 538-554. (doi:10.1111/j.1463-1326.2005.00545.x)

Shoupe D \& Lobo RA 1984 The influence of androgens on insulin resistance. Fertility and Sterility 41 385-388.

Simpson ER \& McInnes KJ 2005 Sex and fat - can one factor handle both? Cell Metabolism 2 346-347. (doi:10.1016/j.cmet.2005.11.010)

Singh AB, Hsia S, Alaupovic P, Sinha-Hikim I, Woodhouse L, Buchanan TA, Shen R, Bross R, Berman N \& Bhasin S 2002 The effects of varying doses of $\mathrm{T}$ on insulin sensitivity, plasma lipids, apolipoproteins, and C-reactive protein in healthy young men. Journal of Clinical Endocrinology and Metabolism 87 136-143. (doi:10.1210/jc.87.1.136)

Singh R, Artaza JN, Taylor WE, Gonzalez-Cadavid NF \& Bhasin S 2003 Androgens stimulate myogenic differentiation and inhibit adipogenesis in C3H 10T1/2 pluripotent cells through an androgen receptor-mediated pathway. Endocrinology 144 5081-5088. (doi:10.1210/en.2003-0741)

Smith P, Rhodes NP, Ke Y \& Foster CS 2002 Upregulation of estrogen and androgen receptors modulate expression of FGF-2 and FGF-7 in human, cultured, prostatic stromal cells exposed to high concentrations of estradiol. Prostate Cancer and Prostatic Diseases 5 105-110. (doi:10.1038/sj.pcan. 4500571)
Soler JT, Folsom AR, Kaye SA \& Prineas RJ 1989 Associations of abdominal adiposity, fasting insulin, sex hormone binding globulin, and estrone with lipids and lipoproteins in post-menopausal women. Atherosclerosis 79 21-27. (doi:10.1016/0021-9150(89)90029-4)

Stellato RK, Feldman HA, Hamdy O, Horton ES \& McKinlay JB 2000 Testosterone, sex hormone-binding globulin, and the development of type 2 diabetes in middle-aged men: prospective results from the Massachusetts male aging study. Diabetes Care 23 490-494. (doi:10.2337/diacare.23.4. 490)

Storer TW, Woodhouse L, Magliano L, Singh AB, Dzekov C, Dzekov J \& Bhasin S 2008 Changes in muscle mass, muscle strength, and power but not physical function are related to testosterone dose in healthy older men. Journal of the American Geriatrics Society 56 1991-1999. (doi:10.1111/j.15325415.2008.01927.x)

Sugden MC \& Holness MJ 2006 Mechanisms underlying regulation of the expression and activities of the mammalian pyruvate dehydrogenase kinases. Archives of Physiology and Biochemistry 112 139-149. (doi:10.1080/ 13813450600935263)

Sweeney G, Somwar R, Ramlal T, Volchuk A, Ueyama A \& Klip A 1999 An inhibitor of p38 mitogen-activated protein kinase prevents insulinstimulated glucose transport but not glucose transporter translocation in 3T3-L1 adipocytes and L6 myotubes. Journal of Biological Chemistry 274 10071-10078. (doi:10.1074/jbc.274.15.10071)

Tenover JS, Matsumoto AM, Plymate SR \& Bremner WJ 1987 The effects of aging in normal men on bioavailable testosterone and luteinizing hormone secretion: response to clomiphene citrate. Journal of Clinical Endocrinology and Metabolism 65 1118-1126. (doi:10.1210/jcem-65-6-1118)

Tivesten A, Mellstrom D, Jutberger H, Fagerberg B, Lernfelt B, Orwoll E, Karlsson MK, Ljunggren O \& Ohlsson C 2007 Low serum testosterone and high serum estradiol associate with lower extremity peripheral arterial disease in elderly men: the MrOS study in Sweden. Journal of the American College of Cardiology 50 1070-1076. (doi:10.1016/j.jacc.2007.04.088)

Traish AM, Guay A, Feeley R \& Saad F 2009 The dark side of testosterone deficiency: I. Metabolic syndrome and erectile dysfunction. Journal of Andrology 30 10-22. (doi:10.2164/jandrol.108.005215)

Wannenes F, Caprio M, Gatta L, Fabbri A, Bonini S \& Moretti C 2008 Androgen receptor expression during C2C12 skeletal muscle cell line differentiation. Molecular and Cellular Endocrinology 292 11-19. (doi:10. 1016/j.mce.2008.05.018)

Wende AR, Huss JM, Schaeffer PJ, Giguere V \& Kelly DP 2005 PGC-1alpha coactivates PDK4 gene expression via the orphan nuclear receptor ERRalpha: a mechanism for transcriptional control of muscle glucose metabolism. Molecular and Cellular Biology 25 10684-10694. (doi:10.1128/ MCB.25.24.10684-10694.2005)

Wolfe R, Ferrando A, Sheffield-Moore M \& Urban R 2000 Testosterone and muscle protein metabolism. Mayo Clinic Proceedings 75 (Supplement) S55-S59 (discussion S59-S60).

Zhang F, Lavan B \& Gregoire FM 2004 Peroxisome proliferator-activated receptors as attractive antiobesity targets. Drug News \& Perspectives 17 661-669. (doi:10.1358/dnp.2004.17.10.873918)

Zitzmann M 2008 Effects of testosterone replacement and its pharmacogenetics on physical performance and metabolism. Asian Journal of Andrology 10 364-372. (doi:10.1111/j.1745-7262.2008.00405.x)

Received in final form 22 April 2011
Accepted 1 June 2011

Made available online as an Accepted Preprint 1 June 2011 